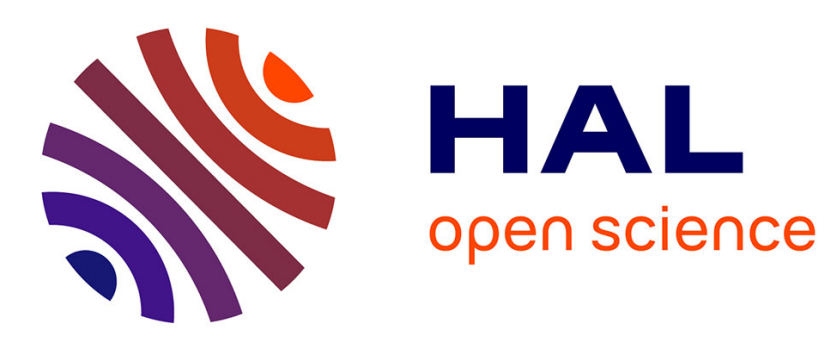

\title{
EXAFS Investigations of Metal Organic Synthesis Tools
}

\author{
T. Ertel, W. Hörner, I. Abraham, H. Bertagnolli
}

\section{To cite this version:}

T. Ertel, W. Hörner, I. Abraham, H. Bertagnolli. EXAFS Investigations of Metal Organic Synthesis Tools. Journal de Physique IV Proceedings, 1997, 7 (C2), pp.C2-947-C2-948. 10.1051/jp4:1997295 . jpa-00255369

\section{HAL Id: jpa-00255369 https://hal.science/jpa-00255369}

Submitted on 1 Jan 1997

HAL is a multi-disciplinary open access archive for the deposit and dissemination of scientific research documents, whether they are published or not. The documents may come from teaching and research institutions in France or abroad, or from public or private research centers.
L'archive ouverte pluridisciplinaire HAL, est destinée au dépôt et à la diffusion de documents scientifiques de niveau recherche, publiés ou non, émanant des établissements d'enseignement et de recherche français ou étrangers, des laboratoires publics ou privés. 


\title{
EXAFS Investigations of Metal Organic Synthesis Tools
}

\author{
T.S. Ertel, W. Hörner, I. Abraham and H. Bertagnolli \\ Universität Stuttgart, Institut für Physikalische Chemie, Pfaffenwaldring 55, 70569 Stuttgart, Germany
}

\begin{abstract}
Grignard Compounds $\mathrm{RMgX}(\mathrm{R}=$ organic group; $\mathrm{X}=\mathrm{Cl}, \mathrm{Br}, \mathrm{I})$ are common tools in inorganic and organic synthesis. The structure of these substances in solution, however, is unknown. To answer this question we performed EXAFS measurements at the Br-K-edge in absorption mode and at the $\mathrm{Mg}$-K-edge in fluorescence mode. From these complementary data a consistent model of the structure of the investigated Grignard compounds in solution is deduced. A similar class of reagents are Reformatsky compounds $\mathrm{RZnBr}(\mathrm{R}=$ organic group), which possess a very high chemical selectivity in contrast to the Grignard compounds. In order to determine the degree of association in solution we performed EXAFS measurements at the $\mathrm{Zn}-\mathrm{K}$-edge as well as at the $\mathrm{Br}$-K-edge. To learn more about the chemical behavior we varied the organic residue and the solvent. Carbenoids of the general formula $X C-\left(R_{1} R_{2}\right)_{2}-M$ $\left(\mathrm{R}=\right.$ organic group; $\mathrm{M}=$ metal, e.g. $\mathrm{Li}, \mathrm{Mg} ; \mathrm{X}=$ leaving group, e.g. $\mathrm{Cl}, \mathrm{Br}, \mathrm{I}, \mathrm{NO} \mathrm{O}_{2}$ ) are modern tools in the synthesis of chiral organic compounds, but have the disadvantage to decompose at temperatures higher than $-50^{\circ} \mathrm{C}$. In detail we investigated $\mathrm{Mg}\left[\mathrm{Ph}-\mathrm{CH}_{2}-\mathrm{C}(\mathrm{H}) \mathrm{Br}\right]_{2}$ disolved in THF. From the EXAFS spectroscopical determined data it was possible to derive a detailed structure model, especially to determine the geometry of the $\alpha$-carbon atom.
\end{abstract}

\section{INTRODUCTION}

In inorganic and organic synthesis particular reagents (synthesis tools) play a key role for the chemo-, regio- and stereoselectivity of the performed reactions. Inevitably, the knowledge of structure data of these compounds under real chemical conditions (homogeneous solution) is very important for the synthesis planning.

\section{EXPERIMENTAL DETAILS AND DATA EVALUATION}

The EXAFS experiments of the Grignard compounds at the Br-K-edge were performed in transmission mode at the beamline RÖMO II at HASYLAB Hamburg, at RT and $-85^{\circ} \mathrm{C}$, using a $\mathrm{Si}<311>$ double crystal monochromator under ambient conditions $(5.4 \mathrm{GeV}$, beam current $50 \mathrm{~mA})$. Corresponding measurements at the $\mathrm{Mg}$ - $\mathrm{K}$-edge were carried out in fluorescence geometry with an UHV compatible cell for liquid samples [1] with the HE-PGM-2 monochromator at BESSY Berlin. All other investigations were performed at $\mathrm{K}$-edges ( $\mathrm{Zn}, \mathrm{Br}$ ) at SERC Daresbury Laboratory at station 9.2 , using a $\mathrm{Si}<220>$ double crystal monochromator under ambient conditions $(3.0 \mathrm{GeV}$, beam current $200 \mathrm{~mA}$ ). For all measurements in transmission geometry ion chambers were used for data collection. Energy calibration was monitored with corresponding metal foils and in the case of the $\mathrm{Br}-\mathrm{K}$-edge with an anhydrous $\mathrm{MgBr}_{2}$ sample. All measurements were performed under an inert gas atmosphere with sample cells suitable for measuring air- and moisture-senstive solutions $[1,2]$.

Data were analyzed with a program package, specially developed for the requirements of liquid and amorphous samples, which is described in detail elsewhere [3]. The curve fitting procedure was either performed with amplitude and phase functions calculated with the program FEFF V3.25 implemented in our own program package [3] or with the amplitude and phase functions included in EXCURV90. The number of parameters that were determined corresponds to the number of independent data points and the test of Joyner et al. was applied.

\section{INVESTIGATED SYSTEMS}

\subsection{Grignard Compounds}

In a previous study we have investigated Grignard compounds only at the Br-K-edge [4]. From the determined structure data it was not possible to answer unrestrictedly the question concerning the geometry of the dimeric spe-

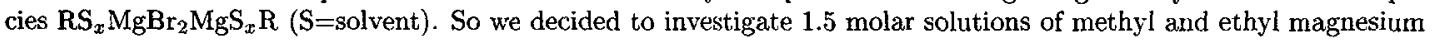


bromide in $\mathrm{n}-\mathrm{Bu}_{2} \mathrm{O}$ at $\mathrm{RT}$ and $-85^{\circ} \mathrm{C}$ again at the $\mathrm{Br}$ - $\mathrm{K}$-edge but also at the difficultly accessible $\mathrm{Mg}-\mathrm{K}$-edge in terms of experimental conditions (highly reactive liquid compounds in UHF). From the evaluated absorber-backscatterer distances (see Fig. 1a) and the co-ordination number of the magnesium backscatterer, the structural model shown in Fig. 1a can be deduced. The data from the $\mathrm{Mg}-\mathrm{K}$ - and $\mathrm{Br}$-K-edge are consistent with each other and the temperature has only a minor effect on the structure in solution. Summarizing the results, the Grignard compounds can be described with an equilibrium between tetrahedral monomers und tetrahedral distorted dimers.

\subsection{Reformatsky Compounds}

Reformatsky compounds are chemically equivalent to the above described Grignard compounds except for the metal atom. This fact increases the selectivity of these reagents. As no convincible structure model exists for the Reformatsky compounds in solution we performed EXAFS mesaurements of $\mathrm{BrZnCH}_{2} \mathrm{COOR}\left(\mathrm{R}=\mathrm{Me},{ }^{t} \mathrm{Bu}\right)$ in THF and the very polar DMSO (each 1.5 molar) at both available edges $(\mathrm{Zn}, \mathrm{Br}$ ). The measurements at the $\mathrm{Br}$-K-edge exclude a dimerisation over the halogen atoms like for Grignard compounds, because only one $\mathrm{Zn}$-atom can be detected and no Br-backscatterer is found. An infuence of the solvent can be detected with the experiments at the $\mathrm{Zn}$ - $\mathrm{K}$-edge. Dissolved in THF the obtained co-ordination numbers and distances confirm a structure model which is based on XRD, IR and NMR measurements and suggest a dimeric species [5] (see Fig. 1b). The data of the species dissolved in DMSO, however, lead to an other model. We found two S-atoms, which belong to the solvent DMSO. This is only possible, if the compound exists as a monomer (see Fig. 1c).

\subsection{Mg-Br Carbenoid}

The main reason why carbenoids are interesting for modern synthesis is their high stereoselectivity leading to chiral products. Nevertheless, only little information is available about the structure, which should explain the interesting reaction behaviour of these species. As many carbenoids are only stable in solution at temperatures below $-40^{\circ} \mathrm{C}$ we performed an EXAFS investigation at the $\mathrm{Br}-\mathrm{K}$-edge of $\mathrm{Mg}\left[\mathrm{Ph}-\mathrm{CH}_{2}-\mathrm{C}(\mathrm{H}) \mathrm{Br}\right]_{2}$ dissolved in $\mathrm{THF}$ at $-50^{\circ} \mathrm{C}$ (see Fig. 1d). The determined absorber-backscatterer distances are given together with a structure model in Fig. 1d and show interesting features concerning the structure of the $\alpha$-carbon atom. The bond length of $2.00 \AA$ between $\mathrm{Br}$ and $\mathrm{C}$ is longer than most $\mathrm{C}-\mathrm{Br}$ bonds (about $1.92 \AA$ ). This agrees with the results of XRD of other Li and Mg carbenoids and theoretical calculations and is typical for carbenoids [6]. The distance between $\mathrm{Br}$ and $\mathrm{Mg}$ is remarkably short and can be interpreted as a coordinative bonding, which is already suggested for other carbenoids. From this results it can be concluded that the correlating $\mathrm{Br}-\mathrm{C}-\mathrm{Mg}$ bond angle must be smaller than the typical tetrahedral angle $\left(109.48^{\circ}\right)$. With an estimated bond length of $2.15 \AA$ between carbon an $\mathrm{Mg}$ the angle decreases to $94.5^{\circ}$. Longer bonds, which are proposed in other studies leads to smaller angles (e.g. $2.20 \AA$ leads to $93^{\circ}$ ). Such a distorted geometry of the sp3-carbon atom and the small distance between $\mathrm{Br}$ and $\mathrm{Mg}$ explain the high reactivity of this compound.

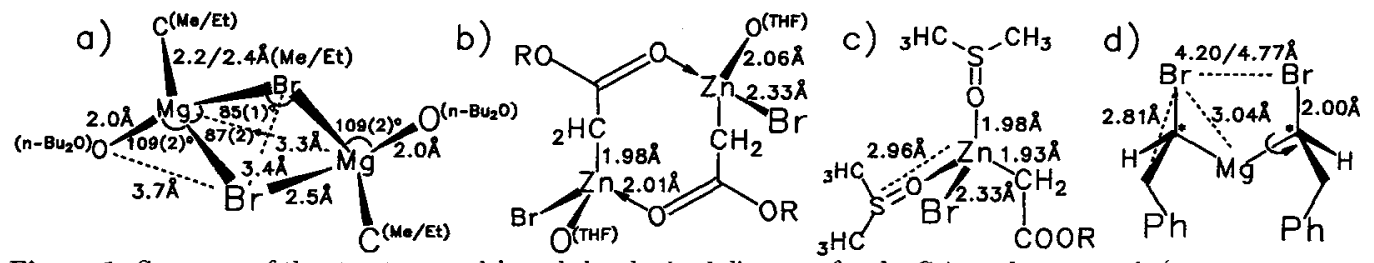

Figure 1: Summary of the structure models and the obtained distances for the Grignard compounds (a, average distances), the Reformatsky compounds (b,c) and the $\mathrm{Mg}-\mathrm{Br}$ carbenoid (d).

\section{Acknowledgements}

We wish to thank BESSY, HASYLAB and the SERC Daresbury Laboratory for the provision of synchrotron radiation. The author T. S. Ertel wishes to thank the Dr. Leni Schöninger-Stiftung for generous financial support.

\section{References}

[1] Abraham I., Hörner W., Ertel T. S. and Bertagnolli H. Polyhedron in press.

[2] Ertel T. S. and Bertagnolli H. Nucl. Instr. Meth. in Phys. Res. Sec. B73 (1993) 769.

[3] Ertel T. S., Bertagnolli H., Hückmann S., Kolb U. and Peter D. Appl. Spectrosc. 46 (1992) 690.

[4] Ertel T. S. and Bertagnolli H. Polyhedron 12 (1993) 2175.

[5] Dekker J., Budzelaar P. H. M., Boersma J. and van der Kerk G. J. M. Organometallics 3 (1984) 1403.

[6] Boche G., Harms K., Marsch M. and Müller A. J. Chem. Soc., Chem. Commun. (1994) 1393. 